\title{
Celebrating 35 Years of the AJNR
} January 1982 edition

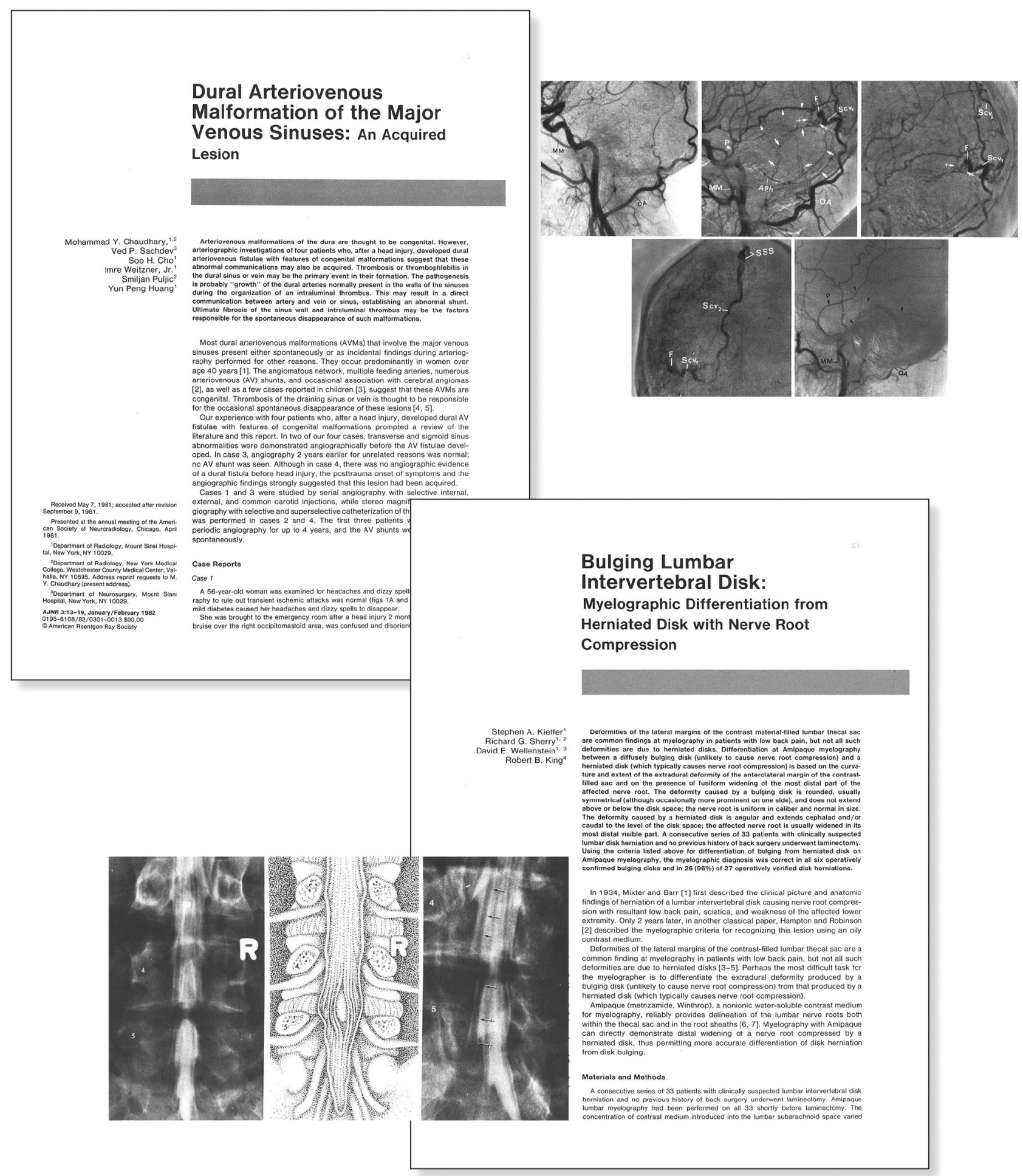

